\title{
DOING AND MAKING IN A DEMOCRACY
}

\author{
John Dewey
}

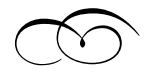

Understanding has to be in terms of how things work and how to do things. Understanding, by its very nature, is related to action; just as information, by its very nature, is isolated from action . . . only . . . by accident.

-John Dewey

dvancing a claim once regarded as radical and still widely mis-
understood, John Dewey argued that most of his philosophical predecessors, even those who had claimed the methods of science as their own, had been guilty of a failure to recognize the importance of technology. ${ }^{1}$ He suggested this was due in part to their prejudice against the impermanent materials used by artisans and craftspeople, in part to their tendency to deprecate the social classes whose members have traditionally dealt with doing and making in the practical sphere, and in part to their rejection of what he took to be the democratizing tendencies of technological methods.

Analysis of the web of technical artifacts and methods that humankind weaves, lives in, and works in was for Dewey a lifelong task. ${ }^{2}$ His early work, between 1892 and 1898, exhibits a preoccupation with the relations between the sciences and the industrial arts and between what were then known as "normal" and "technical" schools. His middle work, from 1899 to 1924 , contains discussions of the ways in 
which intelligence is related to the use of technological artifacts, and of the ways in which concrete tools such as agricultural implements are related to less tangible tools, such as logical connectors.

Dewey's later work, from 1925 until his death in 1952, including Experience and Nature (1925) and Art as Experience (1934), developed these themes in detail. He articulated an account of the philosophical implications of technology during its classical, modern, and contemporary periods, and he anticipated many of the issues and debates which now occupy those working in the philosophy of technology. In this connection, chapters four and five of Experience and Nature, central chapters in what is regarded by many as Dewey's most important work, are devoted almost entirely to a critique of technology. Moreover, those of his later works that focus on science, education, religion, and democracy are richly furnished with examples and metaphors from the technical sphere.

It was Dewey's contention that his philosophical predecessors had for the most part misplaced technology with respect to science, metaphysics, and social thought. Plato and Aristotle, each in his own distinctive way, had attempted to relocate technology outside the work of the artisan and outside the interactions between humans and changeable matter. Plato, especially in the Timaeus, did this by establishing a kind of grand artisan outside the realm of nature. Aristotle did so by making nature itself the grand artisan whose task it is to establish fixed ends fit to be contemplated as ends-in-themselves, not as instruments for further ends.

What resulted was not just a perversion of technology, but a stunting of the growth of science and social inquiry as well. The Republic richly documents the consequences for social thought in general, and for democracy in particular, of this turn against experience in its fullbodied sense. It is there that Plato relegates techne, the activities of the technical artisan, to the lowest rung of his socio-political hierarchy, and at the same time characterizes an attenuated and immaterial form of techne, that of the totalitarian social engineer, as the purest and most important of social activities. 
It was Dewey's contention that Plato had placed the artisan at the bottom of the social hierarchy for the same reason that he had so adamantly demanded censorship of the plastic and dramatic artists: the methods of techne are too powerful to be left in the hands of artists and craftsmen. Unhindered by the repressive legislation of the perfect guardians, the practitioners of techne in its concrete sense would have proved a threat to the "thinkers" of the Republic.

As for Aristotle, it was Dewey's view that the Politics fosters a view of the city-state so constructed that its justification rests on ends "given" by nature. The activities of the practitioner of techne are, as they were in Plato, refined and sublimated. For Aristotle, however, the beneficiary of his transference is not a system of supernature contemplated by the philosopher-king but nature itself, which becomes the grand artisan. Just as Plato had, but less perniciously so, Aristotle plundered the creative and social significance of the artisan's work and relocated its content elsewhere. ${ }^{3}$

Dewey read the Greek attitudes toward science as part and parcel of their unfortunate attitude toward techne. He argued that the Greeks' abhorrence of the mutability inherent in the tasks and materials of technology had led to a science of "demonstration," a science of contemplation, an attempt to possess something already finished, "out there" and complete. In fact, they had invented not so much science as the idea of science. He issued the warning that when inquiry is focused in the sphere of objects esteemed for their own intrinsic qualities - whether that sphere be supernatural or extranatural, as it was for Plato, or natural and immanent but complete, as it was for Aristotle-then such inquiry will fail to increase our knowledge of things as they are, whether that inquiry concerns itself with materials and artifacts, conceptual models of nature, or the ways in which social organization takes place.

As for modern science, the science of Copernicus, Galileo, Kepler, and Newton, it was Dewey's view that its advances were attributable more to what its practitioners were doing than to what they thought they were doing. While the novelty of their theories certainly advanced the practice of their science, their metatheory-their metaphysics and epistemology — often failed to grasp the novelty in those 
theories. Dewey had high praise for the new mathematical techniques of substitution, and suggested that they constituted a "system of exchange and mutual conversion carried to its limit." The objects of science thus became "amenable to transformation in virtue of reciprocal substitutions" (LW 1.115). But the metaphysics and epistemology of the new science were still wedded to the old ideas of a finished universe.

Dewey's claims in this regard are by no means uncontroversial. Desmond Lee, for example, in the introduction to his translation of the Timaeus, rejects the view that the contempt held by the Greeks for the work of the artisan discouraged experimentation and hindered the development of technology. He argues that the aristocracy of seventeenth-century England, a time and place of enormous technological development, had at least as much disdain for the artisan as had the Greeks. He further suggests that inhibitions of technological development in the classical world were not always aristocratic. The Roman contractor, whom he identified as a "fairly rough type, often a freedman,"4 would certainly have been glad to have profited from technological development if it had been possible for him to do so. Instead, Lee argues, the weakness of ancient metallurgy and a lack of precise instrumentation were among the inhibiting factors. But why should these technological materials and instruments not have developed? Lee suggests that there was a conceptual reason: the Greeks had tied science to philosophy, and "philosophy is concerned to understand rather than to change." ${ }_{5}$ For Lee, the contribution of Galileo to the advancement of experimental science was that he took the technical tools and artifacts available to him, tools and artifacts that had gradually become much more sophisticated than those developed by the Greeks, and used them to "untie" science from philosophy.

Dewey repeatedly rejected any view of philosophy that had as its goal understanding without change, for he thought that understanding of any legitimate sort entails change. He also argued that hope of financial gain, even by the most "rough and ready" of contractors, is in itself insufficient to promote technological development. It may in fact thwart or divert such development. On one point at least, his 
position is consonant with that of Lee. They agree that experimental science requires active transaction with environing conditions.

Dewey thought that his predecessors and contemporaries who failed to see that this is also true of philosophy had not fully appreciated the scientific revolution of the seventeenth century. Put in the socio-political terms by means of which he had analyzed the fate of techne among the Greeks of the fourth century BCE, it was Dewey's contention that the new science of the seventeenth century exhibited a surge of democratic methods and an assertion of adaptive practice. But there was a broad gulf between what the new science said it was doing and what it was actually about.

The official view of what modern science was about was still conservative and authoritarian. Its apologists continued to traffic in antecedent truths, demonstrations, and certitudes. They held fast to what we today call foundationalism and the correspondence theory of truth. Moreover, its metatheory continued in this vein long after the new science had enjoyed the prodigious successes that resulted from its practical commitment to the treatment of natural ends as instruments for further inquiry and transaction with nature, rather than as fixed objects of contemplation. Thus did the practice and first-order theories of seventeenth-century science relocate technology de facto in terms of its new spirit of practical experimentalism, even if its metatheory did not do so. Dewey thought that the genius of the new science was its discovery that "knowledge is an affair of making sure, not of grasping antecedently given sureties" (LW 1.123, Dewey's emphasis).

Nevertheless, many of the metatheorists of seventeenth-century science, among whom were some of the most respected metaphysicians of the time, did not understand that the taproot of the new science was in practice. It was the growing body of tools and artifacts that made systematic science possible.

Contemporary historians of science and technology continue to commit this error. The following description by Daniel Boorstin of the work of Galileo the telescope-maker is illustrative of this mistake: "With no special insight into the science of optics," Boorstin writes, 
"Galileo, a deft instrument-maker, had made his device by trial and error. But if Galileo had been merely a practical man, the telescope would not have been such a troublemaker."6

Dewey would have found in this characterization a vestige of the very mistake made by most of the early philosophers of modern science. His view was that Galileo was not so much proceeding by means of trial and error as he was "thinking" with his materials, inquiring into their possibilities in a way that had much more in common with the activities of the artists and craftsmen of Plato's Greece than the philosophers of the modern period realized. Dewey's view of what Galileo was doing is closer to the description of his activities provided us by Paolo Rossi: "Kepler was to lay the foundation of the new optics in the Paralipomena of 1604 , but it was to be a scientist-technician like Galileo who was to muster up the courage 'to look' by using the telescope. He skillfully transformed a use-object which had progressed only 'through practice,' partly accepted in military circles but ignored by the official scientific establishment, into a powerful instrument of scientific exploration."

Dewey argued that inquiry into materials such as was practiced by Galileo precedes and conditions inquiry of a more conceptual variety. It also informs its methodology and terminates its activity in further concrete application. This was perhaps Dewey's most important contribution to the debates concerning the relations between science and technology. Even though the craftsman who thinks in and with materials may not translate that thought into the conceptual sphere, and conversely even though those who think by means of conceptual tools are frequently unable to bring their work to fruition in practical terms, there is nevertheless no reason to posit a methodological gap between the two enterprises.

It is only the infelicitous social prejudice regarding the media in which inquiry is undertaken, the misunderstanding of the talents and dispositions of those who direct the inquiry, and the unfortunate social and cultural boundaries assumed to exist between those modes of inquiry that perpetuate the appearance of a gap that is not in fact justified from the standpoint of methodology. In short, intelligence 
with respect to materials is fully the equal of intelligence with respect to those enterprises we normally consider "conceptual" (for example, science and social thought). Not only are their methods basically the same, but it is only by the cooperation of each with the other that human knowledge is advanced.

Dewey made this point forcefully in Art as Experience. "Any idea," he wrote, "that ignores the necessary role of intelligence in production of works of art is based upon identification of thinking with use of one special kind of material, verbal signs and words. To think effectively in terms of relations of qualities is as severe a demand upon thought as to think in terms of symbols, verbal and mathematical. Indeed, since words are easily manipulated in mechanical ways, the production of a work of genuine art probably demands more intelligence than does most of the so-called thinking that goes on among those who pride themselves on being 'intellectuals" " (LW 10.52). He was careful to include the "practical" or "technological" arts in this characterization. "Art," he suggested, "denotes a process of doing or making. This is as true of fine as of technological art" (LW 10.53).

It was Dewey's claim, then, that philosophy during its modern period, from the seventeenth to the nineteenth centuries, failed to locate technology properly because its allegiance was still tied to the metaphysics of contemplation, of antecedent truths, demonstration, and certitude. But his analysis did not simply take the part of the Empiricists against the Rationalists. Some modern philosophers, he pointedly reminded us, surrendered the antecedent truths of reason only to accept antecedent truths of sensation. Modern Empiricism, according to his view, committed itself to an equally egregious form of foundationalism.

For the bulk of philosophy in its modern period, nature was thought to be a vast machine. Living in the shadow of Darwin as he did, Dewey rejected the metaphor of the machine and replaced it with the organism. But even to those who have transcended the metaphor of world-as-machine there is still the fact of machines and the problem of how to relate to them. A machine can be contemplated as 
something finished and its workings discovered and admired. Further, it can be examined as something complete but in need of occasional repair. Or it can be treated as something ongoing, unstable, and provisional - as a tool to be used for enlarging transactions of self and society with environing conditions. It was Dewey's contention that the discussions of the nature of the world-as-machine in the seventeenth and eighteenth centuries were primarily focused on the first two of these attitudes. Of course each of these three possibilities involves some level of interaction with nature. But it is only with the third that there comes to be genuine transaction with nature, awareness of such transaction, and inclusion of that awareness in the metatheories of science.

In the political sphere, of course, it was a great advance over the old supernaturalist and extranaturalist views to think of the world as repairable, even if it was not yet fully open to transaction. In Liberalism and Social Action, Dewey praised the advances made by Bentham on just these grounds. But he also warned of treating the world-machine as something to be merely examined and repaired. He cautioned against Bentham's acceptance of humankind as "a reckoning machine" (LW 11.24). The old machine metaphors of Bentham and others neglected the fact that relations between human beings and their political environments are always "relations of ongoing affairs characterized by beginnings and endings which mark them [the ongoing affairs] off into unstable individuals" (LW 1.127). These individual relations are in need of continual and intelligent reevaluation and reconfiguration by means of practical inquiry.

Failure to make this conceptual shift from machine-as-finishedthough-imperfect-and-repairable to machine-as-incomplete-and-unstable-instrument has precipitated in our time a situation well described by Stuart Hampshire in a polemic against Utilitarianism, a cluster of positions against which Dewey also argued. In its emphasis on repair as opposed to transaction, Hampshire suggested, much recent thought has led to "new abstract cruelty in politics, a dull, destructive political righteousness: mechanical, quantitative thinking, leaden academic minds setting out their moral calculation in leaden 
abstract prose, and more civilized and more superstitious people destroyed because of enlightened calculations that have proved wrong." 8

It might be objected that it was during this modern period of science that the United States of America, the most influential democracy of the contemporary world, was founded. It might further be argued that among the framers of that democracy were deists, practitioners of a form of religious faith that explicitly regards God as artisan and a virtually finished universe as His handiwork. But among these social experimenters were also gadget-makers, mechanics, and tinkerers. Thomas Jefferson, whom Dewey greatly admired, consistently spoke of political and social experimentation in a manner that echoed his transaction with clocks, agricultural methods, and gadgets of many sorts. Jefferson repeatedly referred to the government that he helped establish as an experiment, moreover, one whose institutions and laws would be in need of recurring modification by each succeeding generation. For government, as for nature, contemplation had been replaced by examination, and that in turn by experimentation, whose goal was constant attention to possibilities of adjustment and amelioration.

Jefferson's transactionist orientation to technology, to social thought, and to the broader world of his experience stands in stark contrast to the examinationist program of Descartes a little over a century earlier. L. J. Beck gives the following account of Descartes' attitude toward Galileo's telescope as exhibited in his Dioptrique of 1637 and his correspondence with Jean Ferrier:

Already at La Flèche, Descartes had probably heard of the discoveries made by Galileo through the use of the telescope. Descartes wishes to draw up a plan for the construction of an even better one, and above all of a more powerful lens. This cannot be done until, he tells us, it is known, what happens when light traverses several lenses, until the law of refraction has been established and the problem of the linea anaclastica solved. Then only can the plan of the various curves of the lenses be worked out. Descartes works these out but, as one can see, the unfortunate Ferrier is unable to carry out in practice the difficult requirements set by Descartes. Galileo cannot solve the problem of the linea anaclastica; 
he does not know the law of refraction, but he manages to construct an instrument which gives a substantial magnification. Kepler, slightly more theoretical, knew only of approximations to the law of refraction but his description of the telescope provided a working model for future astronomers. Descartes required the exact measurements for his lenses, and failing this, he lost interest in the whole topic. ${ }^{9}$

It was precisely this debate between the transactionist craftsmenpractitioners of modern science and technology and those seeking to examine its hypothetical and metaphysical foundations that was a matter of intense interest to Dewey. It provided evidence for his thesis that metaphysicians of the period had mislocated the place of technological practice. Writing of the controversy between the Cartesian school and that of Galileo and Newton, he lauded the triumph of the latter because of its emphasis on "experience." And his characterization of experience made extensive use of examples of inquiry in the technological sphere (LW 1.14-15). In a rather sad aside he suggested, "We may, if sufficiently hopeful, anticipate a similar outcome in philosophy. But the date does not appear to be close at hand; we are nearer in philosophic theory to the time of Roger Bacon than to that of Newton" (LW 1.15).

Dewey wanted to locate technology in a realm that is neither supernatural nor extranatural, an organic realm in which the only telic elements are those of the natural ends of objects, individuals, and events, all of which in turn may be used as means to further ends. It was his view that the legitimate place of technology is alongside science and social thought as one of several branches of inquiry. On his reading, technology is not inferior to its brother and sister branches, and may in some respects even be more important than they in that its unique qualities serve to inform, enhance, and promote those siblings in ways that they are incapable of reciprocating.

What are these unique qualities? I have already alluded to his commitments to what Don Ihde would later call "the historical-ontological priority of technology over science." ${ }^{10}$ In 1925 Dewey argued the historical component of this claim when he suggested that in spite of 
the obvious fact that "the sciences were born of the arts-the physical sciences of the crafts and technologies of healing, navigation, war and the working of wood, metals, leather, flax and wool; the mental sciences of the arts of political management, . . . it is still commonly [and erroneously] argued that technology is merely 'applied science" " (LW 1.105).

He further argued that modern science "represents a generalized recognition and adoption of the point of view of the useful arts, for it proceeds by employment of a similar operative technique of manipulation and reduction. Physical science would be impossible without the appliances and procedures of separation and combinations of the industrial arts" (LW 1.108).

In addressing the "ontological" (read "functional") component of his claim, Dewey reminded us that what is peculiar to human interaction with the world is not its enjoyment, but the necessity of grappling with it at the technological level and the knowledge, or science, which follows upon that interaction. In Dewey's words, "It was not enjoyment of the apple but the enforced penalty of labor that made man as the gods, knowing good and evil instead of just having and enjoying them" (LW 1.100).

To contrast knowing and having, as Dewey did in this remark, is to allude to his treatment of knowledge as hypothesis, pointing to an unfinished future in which inquiring human beings accommodate themselves to environing conditions, environing conditions are adapted to human needs, and the two processes are jointly known as "adjustment."

This is a view that would re-emerge in Heidegger's essay, "The Question Concerning Technology." Technology is there differentiated into a tool of science, the activities of the craftsman (techne), and, its ultimate sense, aletheia or revealing. It is this last sense of technology that is most basic to Heidegger's account: “Instrumentality is considered to be the fundamental characteristic of technology. If we inquire, step by step, into what technology, represented as means, actually is, then we shall arrive at revealing. The possibility of all productive manufacturing lies in revealing."11 Again, "Technology is a 
mode of revealing. Technology comes to presence . . . in the realm where revealing and unconcealment take place, where aletheia, truth, happens." 12

I have recalled Heidegger's account of the ontological priority of technology over science because of the light it sheds on Dewey's own account. For Dewey, it is technological instrumentality (what Heidegger calls "revealing") that characterizes the most primitive relation between the activities of men and women and the world of their experience. Such instrumentality ties together the myths that tell of the manner in which labor entered the world and the myths that constitute our most up-to-date theories of political economy.

But if technology is prior to science both historically and ontologically, it also is responsible for the prestige enjoyed by science. Dewey argued that the successes of science have been due not so much to what he called "scientific temper" as to "scientific technique." In his essay "Human Nature and Scholarship," Dewey argued that "scientific technique, as distinguished from the scientific temper, is concerned with the methods by which matter is manipulated. It is the source of special technologies, as in the application of electricity to daily life; it is concerned with immediate fruits of a practical kind in a sense in which practical has a special and technical meaning-power stations, broadcasting, lighting, the telephone, the ignition system of automobiles" (LW 11.457). Further, "The inherent idealism of the scientific temper is submerged, for the mass of human beings, in the use and enjoyment of the material power and material comforts that have resulted from its technical applications" (LW 11.458).

What was Dewey's view of the location of technology with respect to epistemology? "Knowledge ceases to be a mental mirror of the universe and becomes a practical tool in the manipulation of matter" (LW 11.457). ${ }^{13}$ Dewey reiterated his radical position in Experience and Nature: "In the practice of science, knowledge is an affair of making sure, not of grasping antecedently given sureties" (LW 1.123).

Dewey not only viewed technology as the primary means of inquiry open to those individuals cut off from what normally goes on 
in laboratories, observatories, and places of special research; he suggested that technology was a special avenue of inquiry open to those individuals living in closed societies where social inquiry is suppressed. But he was neither idealist nor utopian. He knew that even in open societies there would be those who prefer appeals to tenacity, authority, or the a priori to free and open inquiry as methods of fixing their beliefs. It was with this in mind that he suggested that technology may also operate as a buffer between the forces of antiscience and science.

I do not think that he would have been surprised that those who now attempt to promote the teaching of a literal reading of the Genesis myth of creation do so while claiming to march under the banner of science. The advances of science propagated in the technological sphere have made moot many of the old antiscientific arguments, or at least required that they be masked in scientific jargon. Dewey repeatedly demonstrated his conviction that the work of those who take the pluralistic values of free and open inquiry seriously will never be finished. This is a central aspect of his philosophy of education.

But if technology for Dewey forms a buffer between the forces of antiscience and science, it also functions as a means by which science may be appropriated by the scientifically uninformed. There are two ways in which this takes place: not only have the fruits of technology become ubiquitous, but the methods of science, historically and ontologically dependent on technology, may be reintroduced into the field of technological practice and used with new authority. But with these two outcomes of technology — one immediate, the other mediate-come two dangers. The first is the one indicated by José Ortega $y$ Gasset, that technological men and women may become like the aboriginal forest or jungle dweller, just picking the technological fruits as if they had been supplied by a natural system beyond their understanding or control. The second is that technology will once again become mislocated with respect to science, that is, that it will once again suffer the deprecation it suffered during the period of classical, modern, and much of contemporary philosophy. These are 
dangers to social organization in general, and to democracy in particular, because they signal the truncation of the full spectrum of inquiry necessary to the transaction of human beings with their environment and the consequent knowing of things as they are and can be.

In his 1944 essay, "Democratic Faith in Education," Dewey made even more explicit his concern regarding the dangers to technology and to social inquiry. He could have been writing of our current situation when he characterized the first of these dangers as "laissez-faire naturalism." To those who would appeal to the forces of the "invisible hand" or "the [undefined] laws of the marketplace," Dewey had this to say: "Technically speaking the policy known as Laissez-faire is one of limited application. But its limited and technical significance is one instance of a manifestation of widespread trust in the ability of impersonal forces, popularly called Nature, to do a work that has to be done by human insight, foresight, and purposeful planning" (LW 15.253). He applied this assessment to planning in national and international affairs, suggesting that the refusal to apply the methods of the technological sciences in those areas had led to a state of imbalance and "profoundly disturbed equilibrium" (LW 15.254).

A second danger to technological and social inquiry lies in the attitudes and activities of the "humanist" who attacks technology as "inherently materialistic and as usurping the place properly held by abstract moral precepts" (LW 15.255). He suggested that such moral precepts had remained abstract precisely because those defining them had divorced ends from the means by which they are to be realized.

Dewey specifically criticized the Hutchins program, which set out to separate technical training from liberal education-a situation which has both become a fact of our universities and is seen by many as tending to create a permanent social wound as it becomes more widely practiced in our secondary schools. When the putrefaction of the wound is eventually discovered, the blame will likely be located at the door of "technology," and not in its proper place, namely, the failure to apply the inquiry which is characteristic of experimental science and technology at its best to all areas of human endeavor. 
In that same essay Dewey mentioned a third threat to technological and social inquiry. It is consequent on the activities of contemporary Luddites, especially of the theocratic variety. They resist the application of scientific and technical methods to the field of human concerns and human affairs because they tend to think of themselves as outside of and above nature and because they prefer a return to the medieval prescientific doctrine of a supernatural foundation and outlook in all social and moral matters. He further suggested that this group erroneously believes that the methods of science and technology have been applied to every area of human concern-and found wanting.

A special variety of this third faction has become even more militant than it was at the time Dewey issued his warning. Both antiscientific and antidemocratic, Christian fundamentalists of the extreme Right have nevertheless adopted the tools of electronic technology to advance their aims. Dewey was aware that technological advances could be appropriated by authoritarian forces, and discussed this phenomenon in detail in his 1936 essay, "Religion, Science and Philosophy."

The two forces that particularly concerned him in that dangerous year, a year which saw the growing power of Fascism throughout the world, were what he called "political nationalism" and "finance-capital," both important allies of the religious Right in our own time. He called these movements "new religions." They, like religious fundamentalism, depend on the a priori and the putatively revealed as substitutes for intelligent inquiry. They, like religious fundamentalism, have their "established dogmatic creeds, their fixed rites and ceremonies, their central institutional authority, their distinction between the faithful and the unbelievers, with persecution of heretics who do not accept the true faith" (LW 11.460).

They share a further important characteristic of religions: they dote on the terminus a quo rather than on the terminus ad quem, a doctrine of "original intent" rather than a careful attention to consequences. Dewey's Experience and Nature warns of the capture of applied science by these elements: they work to channel it toward "private and economic class purposes and privileges. When inquiry is narrowed by such motivation or interest, the consequence is in so 
far disastrous both to science and to human life" (LW 1.130-31). Dewey reminded us that these potential disasters are not due to the practical nature of technology, but to the defects and perversions of morality as it is embodied in institutions and the effects of such institutions upon personal disposition.

This chapter would remain incomplete were I not to quote an extended passage from an address prepared by Dewey and delivered at a celebration of his eightieth birthday. There is perhaps no more eloquent characterization of the interaction between inquiry at its various technological, scientific, and political levels in all of Dewey's writings. Belief in democracy is there characterized as a

belief in the ability of human experience to generate the aims and methods by which further experience will grow in ordered richness. Every other form of moral and social faith rests upon the idea that experience must be subjected at some point or other to some form of external control; to some "authority" alleged to exist outside the process of experience. Democracy is the faith that the process of experience is more important than any special result attained, so that special results achieved are of ultimate value only as they are used to enrich and order the ongoing process. Since the process of experience is capable of being educative, faith in democracy is all one with faith in experience and education. All ends and values that are cut off from the ongoing process become arrests, fixations. They strive to fixate what has been gained instead of using it to open the road and point the way to new and better experiences.

If one asks what is meant by experience in this connection my reply is that it is that free interaction of individual human beings with surrounding conditions, especially the human surroundings, which develops and satisfies need and desire by increasing knowledge of things as they are. Knowledge of conditions as they are is the only solid ground for communication and sharing; all other communication means the subjection of some persons to the personal opinion of other persons. Need and desire-out of which grow purpose and direction of energy - go beyond what exists, and hence beyond knowledge, beyond science. They continually open the way into the unexplored and unattained future. (LW 14.229) 
